\title{
The Rensselaer Russell House
}

\section{Ann Spencer Kinne}

NESTLED IN THE HEART of northeast lowa is a small jewel of American mid-Victorian architecture. Unnoticed by many of the local inhabitants, but enjoyed by school age and out-of-town groups, the Rensselaer Russell House of Waterloo, lowa stands today as an example of stateliness and graciousness long vanished.

The house is surrounded by medical clinics, motels, and situated just above a financial building, People's Mutual Savings and Loan Association, that now owns the Russell property. Russell House, on its own tiny piece of ground retained from the original property, nevertheless defies the commerical atmosphere and welcomes the visitor to a glimpse of luxurious Victorian living.

Facing Washington Park, the house is one of the last of the old, elegant homes that once dotted this part of town. The impressive Snowden home at 306 Washington was completed some years after the Russell home and is now maintained by the Waterloo Woman's Club as their headquarters. Only the remembrance of the Leavitt home, constructed in 1866, exists across Washington Park. The Museum of History and Science now stands on the Leavitt site at 503 South Street.

Rensselaer Russell started building his home in 1858 as a show place for his era; but he built sturdily for the future in hopes, perhaps, of keeping something intact for the coming age. The house is a monument to a past way of life. An era of Victorian modes of living will not likely come again; Waterloo will not have another or better chance to preserve an important aspect of its past.

Russell was born in Otsego County, New York in June of 1828. His grandfather had come to America almost seventy-five years earlier and, as a carpenter, had traded his skills for land. Since this work included the building of several fine homes for the wealthy, 
there is little doubt that young Russell was familiar with, even if from a distance, some of the great homes of the period. ${ }^{1}$

Apparently the many acres of land acquired by the grandparent meant increased comfort for the new generation, for Rensselaer Russell was able to attend an eastern school, Hartwick Seminary. Sometime thereafter he clerked in a New York City dry goods establishment and must have acquired quite a background in this field as, much later, his varied Waterloo businesses often dealt in the wholesale and retail dry goods fields.

After marrying Caroline Richards in 1853, Russell returned to her father's farm and tried farming for a short time before deciding to travel west to the newly developing state of lowa. Still in the process of settlement, lowa was being lauded by visitors as wide open for profitable settlement with its rich lands and ample wooded areas. $^{2}$

Rensselaer Russell, his wife, and daughter Genevieve, six years old, settled in the small community of Waterloo, some ninety miles from the thriving river town of Dubuque. Settled in 1846, the small prairie town was incorporated in 1854; the population was then about 200 persons. In 1858, just after the Russells arrived, the population had risen to 400 .

Immediately after arrival, Russell began the enterprises that were to establish the family as one of the wealthiest in the Waterloo area. Temporarily lodging his family on Jefferson Street, Russell began a banking concern with Martin $\mathrm{H}$. Moore that lasted only a couple of years when, after the First National Bank opened, Russell transferred his funds to that establishment.

Among other properties purchased by Russell at this time and in the years to come was the locally celebrated Russell Block. In the vicinity of Commercial Street and Fourth, Russell Block consisted mainly of the Russell Building, erected in 1860. The third floor of this building, Russell Hall, was to know many of the holidays that the town would celebrate. The largest meeting place of its kind in Waterloo for many years, the Hall was the communal gathering place

\footnotetext{
${ }^{1}$ Isaiah Van Metre, ed. and comp., "Rensselaer Russell," History of Black Hawk County lowa and its Representatives Citizens (Chicago: Biographical Publishing Company, 1904), 746-47. John C. Hartman, ed., "Rensselaer Russell," History of Black Hawk County lowa and its People (Chicago: S. J. Clarke Publishing Company, 1915), 398-402.

${ }^{2}$ Van Metre, 182.
} 


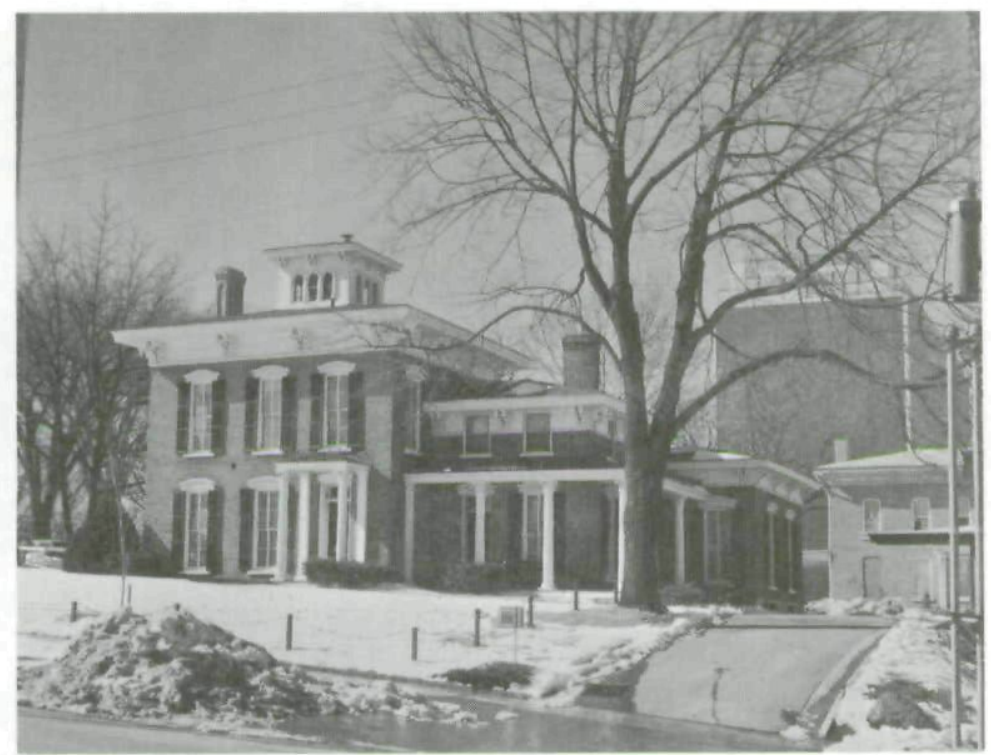

\section{Rensselaer Russell House}

Courtesy of Author

for such diverse activities as church services and a performance by Tom Thumb. After Lincoln's assassination on April 15, 1865, appropriate mourning rites were held in the Hall. Just prior to this sober affair, Lee's defeat and the end of the Civil War had been heralded. "Everything by 8:00 p.m. was illuminated... Russell's Block shed a flood of light. ..."3

Also about the time of the construction of Russell Block, c. 1858 , Russell started work on the small but elegant brick house that was to become a landmark in the community. Brick could not be obtained locally at this time. Although there were excellent raw materials for brick manufacture, such a concern had not been established in the late 1850 s, so brick and other building materials could only be purchased at Dubuque and transported overland by wagon to Waterloo. ${ }^{4}$

${ }^{3}$ Hartman, 173.

${ }^{4}$ Efforts to follow the Cedar River and branches through to Dubuque via Dyersville, lowa had always failed with the exception of an unusual flood year of 1858. A steamer came through much to the joy of the Waterloo townspeople who conveniently forgot that the floods of 1858 had never before been as great. The next season's attempt left the steamer aground long before reaching the Waterloo destination. 
The first railroad train came through in 1861 just at the time the house was completed. Russell's work ledger memorandum of building and labor noted that lime was procured from nearby Cedar Falls, but this same source indicates that some of the lumber was obtained from as great a distance as Chicago, some 275 miles away.

Although not the first brick house (Sullivan Day already had a brick home between Fourth and Fifth Streets and Haddock Tinker had put up a brick structure in 1856, later known as Sedgwick House), the Russell House was the most elegant in the settlement. Many new frame structures were built; the town grew rapidly and the population in 1861 had expanded to 1,800 .

Rensselaer Russell was a methodical man; his personal ledger listing the costs of the house exists today and is on view in the family sitting room. The total recorded cost of the home was $\$ 5,878.83$. Eighty-five thousand bricks, transported from Dubuque, were used at a cost of $\$ 403.11$.

In addition to the house property and the downtown commercial properties, Russell purchased in the early 1860 s a plat of land just across from Russell House. This land, termed Russell Square, in 1872 was given to Waterloo to be known as Washington Park. For years it was the custom to have Fourth of July celebrations at this spot as well as other holiday festivities. The oriental pagoda and oriental gardens now located there, although in distinct contrast to the period of Russell House, afford a lovely view for the home.

Rensselaer Russell was not timid about venturing into new areas, but his major and continuing sources of revenue seemed to come from real estate and the wholesale and retail dry goods and grocery lines. Indeed, until his death in 1896, although he retired from other fields, he continued to be active in real estate.

The Russells suffered a family tragedy just after settling into the new house. Their first daughter, Genevieve, drowned. Reports of the accident conflict: historians note that she came too near the Cedar River, very far from the home. Stories among long-standing Waterloo residents speculate that the child fell into an uncovered well. In any case, the death was one which the family felt greatly. A second daughter, Lillian, was not born until 1869. She was very close to her parents and remained, in spite of marriage, very much a Russell throughout an active business life.

After Russell's death in 1896, Lillian married Clyde Orrin 
Lamson. ${ }^{5}$ Since Lillian had kept house for her father after her mother's death in 1887 and since Lamson was something of a newcomer to Waterloo, it must have seemed natural for the newly married Lamsons to continue to live in the Rensselaer Russell House. Lamson applied himself to the family enterprises left to Lillian. In 1899, jointly with his wife, he erected the Russell-Lamson Building. $\mathrm{He}$ also occupied himself with banking, manufacturing and real estate.

Lillian Russell Lamson seems an astonishing person for her day. In an age when many wealthy midwestern women restricted themselves to their home affairs, Lillian Lamson continued in her father's business activities. In 1911, she graduated from Gate Business College in Waterloo and became active in the Waterloo Business Women's Association. Perhaps this independence came early for, after graduation from West Waterloo High School, she earned a degree from a Canadian college and later studied piano with a private instructor in Chicago. Correspondence with Steinway and Sons in March, 1971 disclosed the fact that the Steinway grand piano now in the home was purchased from Long Island City, New York in 1891 probably by Russell for his daughter. Mrs. Lamson obviously felt the strength of her family's early achievements. In 1914 when the impressive Russell-Lamson Hotel at Fifth and Commerical Streets was erected, again both family names were used.

The Lamsons had two children, Russell Orrin Lamson and Maxine Russell Lamson (Mrs. D. E. Gerow). Russell O. Lamson still resides in Waterloo; Mrs. Gerow is deceased. After Lillian Russell Lamson's death in 1946, the property reverted to her son Russell and his wife, Pauline. They renovated the home and resided there until 1962 when the house and grounds were purchased by People's Mutual Saving and Loan Association.

On a tour of the house today, the visitor sees the exterior essentially as it was in 1861, although the grounds are much reduced in size and the fence surrounding the original property is gone. The small porch opens onto a largish central hall that ends, not at the rear of the house, but just beyond the parlor and the oppositely

\footnotetext{
${ }^{5}$ Clyde Lamson also had a varied career before settling in Waterloo. Born at Waverly, lowa in 1873, he graduated from the State University of Iowa School of Pharmacy in 1894. He clerked for one year in a Waterloo drug store, for a short time in a similar enterprise in Hampton, lowa and then, until 1896. assisted in his uncle's pharmacy in Anamosa, lowa.
} 


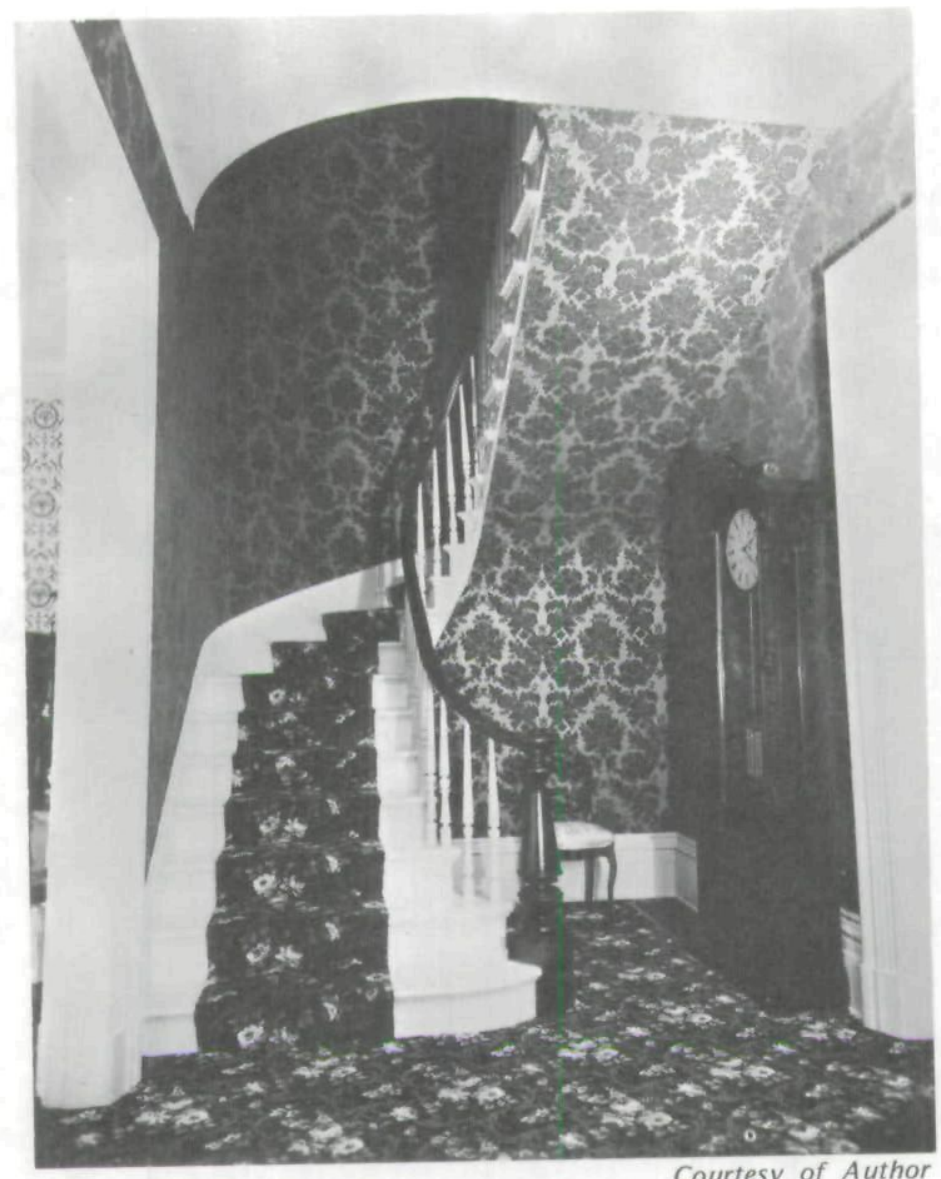

\section{Entrance hall and stairs in the Russell House}

placed sitting room doors. A stairway ascends from the back of the hall to the second storey. This stair was designed by Russell to be a central feature of the house; it rises in a curve of well-polished wood from the downstairs hall to the second floor landing and, in early years, continued the curve in a spiral that ended in the cupola perched on the roof. One is tempted to wonder what Waterloo settlers of the 1860 s must have thought of this delightful, albeit nonessential piece of luxury.

The removal of this railing, accomplished sometime probably in the first half of the 1900 s allowed for some of the rooms on the 
second floor to be made more spacious. The interior of the hall ceiling was extended to cover the cupola opening, so that from the inside no remnants of this design can be seen.

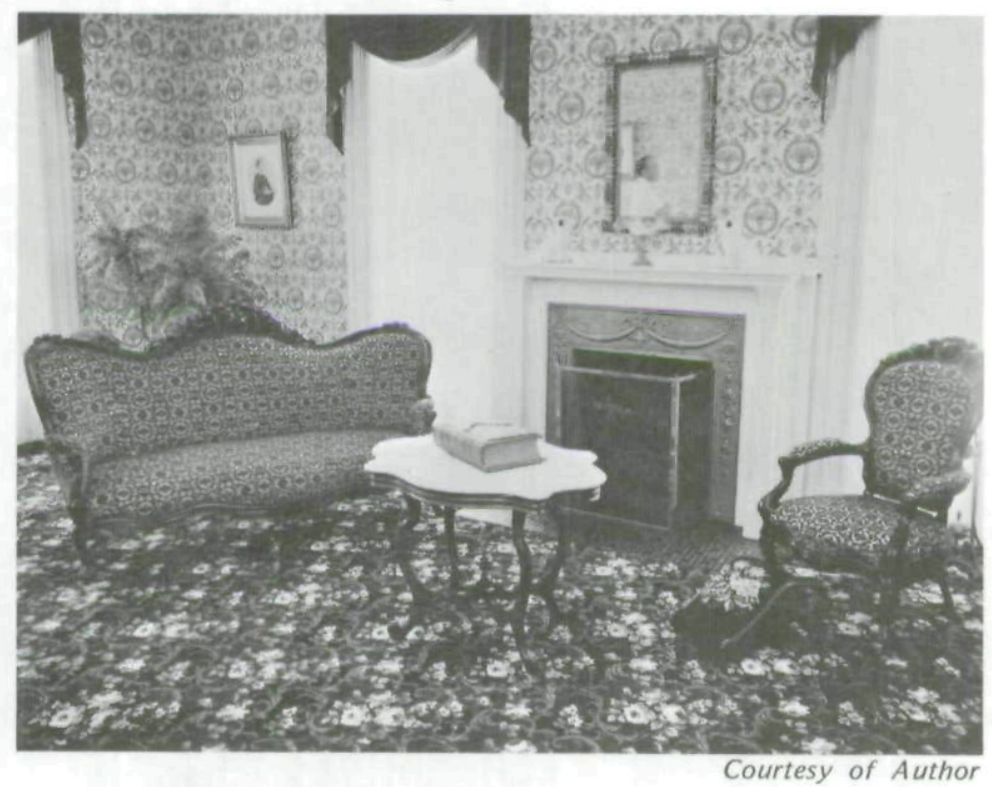

Parlor in the Russell House

The lower entrance hall, small but formal, opens into the family sitting room at the right and the elegant parlor on the left. This parlor is easily the largest and most striking room in the house as it was surely meant to be in 1861. Although most of the present furnishings are additions to the home donated or loaned by local inhabitants and thus were placed during the restoration project of the 1960s, the Steinway grand piano, the hall grandfather clock and the two floor-to-ceiling mirrors in the downstairs rooms are original to the house. The white woodwork of the downstairs was repainted during the restoration, but painted woodwork was an original and slightly unusual feature of the Russell house. The present decor was designed to reflect a wealthy home of later Victorian times and does this job proudly. Gorgeous "Turkey red" was chosen for the elaborate and striking carpeting and for the floral and flocked wallpaper in the parlor. This paper and carpet are also used for the hall and stairs so the vibrant tones echo through the house as viewers note the downstairs rooms and as they ascend the spiral stairs. 
The sitting room, at the righthand entrance, has an area rug placed upon well-buffed flooring. An immense desk showing Russell's ledger is one of the main features of this room. The fireplace (now in the parlor) was once also a prominent feature of this room. Used in the manner of the present-day "family room," most of the family gathering was done in this area and the fireplace was a necessary comfort.

Windows from floor to ceiling are featured here as they are in the rest of the lower rooms. Velvet drapes and swags outline the windows and are placed over frothy lace-like inner curtains. Red is repeated in here, but the general atmosphere is much more casual than in the very elegant main parlor.

At the rear of the sitting room is the entrance to the dining room. The dining area, in turn, has a lefthand door into the kitchen and a third door at the rear that allows the only entrance into the original tiny office situated on the northwest corner of the first floor.

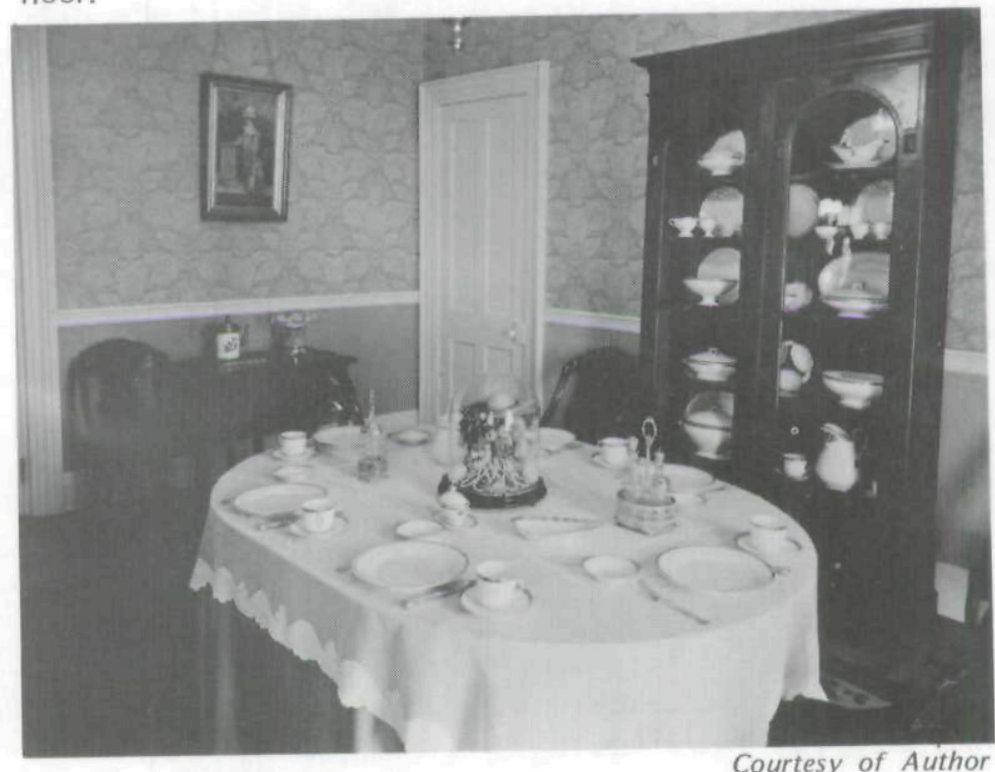

Dinning room in the Russell House

As of 1973 the kitchen entrance from the sitting room was completely removed. This change from the original house design was 
necessitated by the extensive kitchen renovations that were completed during the summer of 1972.

Changing the original floor plan of a restoration is not usually desirable. In this case, however, the kitchen-bath area had undergone several major and minor family modernizations between the late 1800 s and the 1960 s so that the restoration project of the 1960s was designed to meet the future needs of a Victorian museum. A more desirable tour route through the house was needed and so the kitchen entrance was removed. This served the additional purpose of giving more space to the kitchen.

A small, modern half-bath is located off the dining room and sandwiched between the kitchen area and the office area. It appears from blueprints of the 1947 renovations by Russell Lamson and his wife, that this bath area was probably, in 1861, a portion of the kitchen, perhaps a small pantry. The bath is not considered a part of the house tour although an attempt to maintain some early decor has been made.

Tucked beyond the dining room, with its very comfortable proportions, is the tiny and secluded office. Used as a store room for many years after Russell's death, the office was restored in the late 1960 s and now includes a proper and huge writing desk. Pictures of early Waterloo and other memorabilia of the town and of the Russells are located here.

The kitchen was finished in the styles of the later 1800s. This is the only room area that has undergone successive changes since construction in 1861. These successive changes meant that the original 1861 features had been obscured and, since the original floor plans had not been found by 1972, the adaptations used in the redesigning fit present museum needs rather than pay strict attention to the original design.

On the upper floor, the large master bedroom, situated at the front of the house on the southeast corner, is located over the parlor. A small child's room, also above the parlor, is immediately behind this large bedroom. This room was the original nursery and only had access from the parents' bedroom. Built for Genevieve, the room was occupied by Lillian after her birth in 1869. The stairway to the cupola, already mentioned, occupied almost half of this child's bedroom behind the parents' room. The original area must have contained only a bed and perhaps a very small wardrobe. 


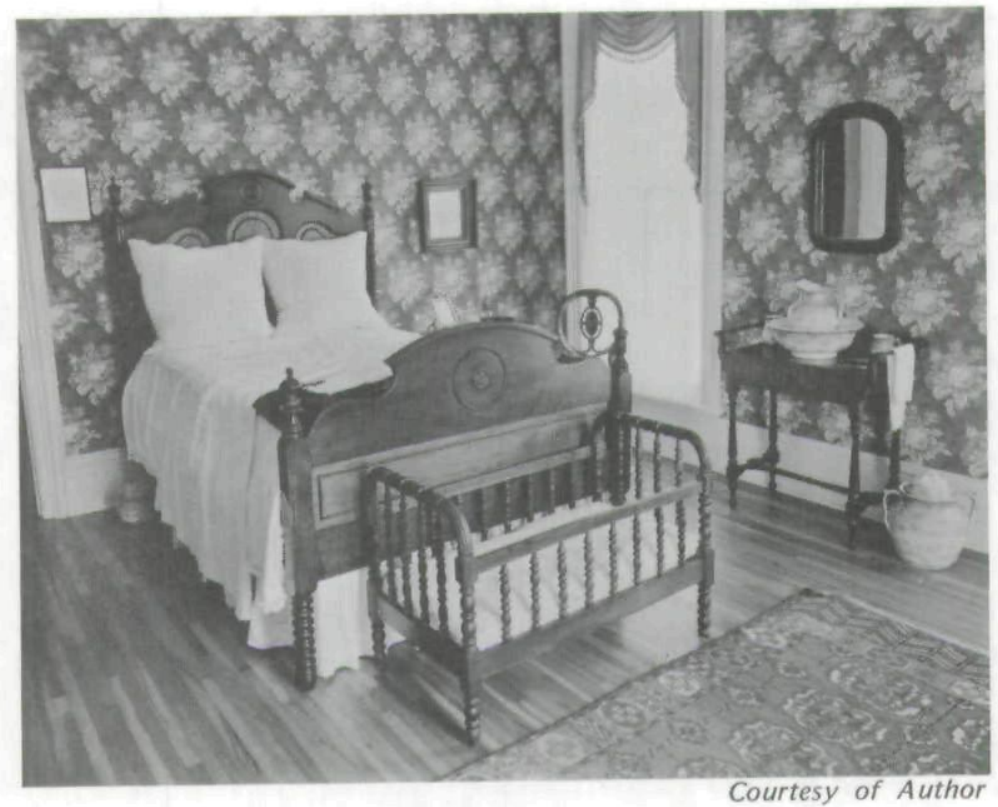

Master Bedroom in the Russell House

In designing the house, style was generally considered before personal comfort. Mrs. Russell Lamson, wife of Rensselaer Russell's grandson, speculated that since the upper exterior windows had to be enlarged to admit more light, the exterior appearance had been for elegance rather than interior convenience. ${ }^{6}$

One of the still incomplete areas in the upstairs is the small room at the head of the stairs just across the landing. At present this room is a bath/storage area. Originally, there was a door from this space into the master bedroom and the room was a walk-in closet into the large bedroom. It is possible that there was not, in 1861 , a door into the hall as there is now. That closet became a bath probably during the early married years of Lillian and Orrin Lamson. Restoration plans for this room have not yet been formulated.

Across the landing from the two main bedrooms and situated on the north side of the house are the original servant's quarters. Two typically narrow and cramped rooms for the live-in housekeeper and her husband, the stable and yard man, seem by present standards

${ }^{6}$ Waterloo Sunday Courier, September 28, 1947. 
unsuitably tiny. The back stairway opening from the rear of the quarters is very, very steep.

The restoration project of the 1960 s converted the front maid's room (her sitting room) into a nursery. The rear maid's room has been decorated and remains a servant's room. It is this space that has the door leading to the kitchen by means of the back stairs. Otherwise the maid's room has access to the main hall only through the nursery.

Changes in the house from 1861 to the present day, when itemized, seem minimal. During Rensselaer Russell's lifetime, the home apparently was left as it was when built. There is one minor mystery: a parquet-edged flooring in the dining room is laid over the original floor. Since Russell Lamson, the grandson who resided in the home from 1947 to 1964 , did not recall when this was done, it is possible that Rensselaer Russell himself may have made the change. It is interesting to reflect that R. Russell possibly felt that the original floor was not grand enough for the home that he envisioned and that he erected a second layer of flooring over the still adequate first one.

After People's Mutual Savings and Loan Association bought the house in 1963, they leased it to the Junior League of Waterloo and Cedar Falls for $\$ 1.00$ a year. The League then began the extensive restorations that were to culminate successfully in the establishment of a permanent board of civic volunteers to continue the restorations. The Board, the Association for the Preservation of the Rensselaer Russell House, has continued to renovate and hopes to make the house a permanent part of Waterloo historical and cultural activities. In the Summer of 1973 the house became the thirtyeighth lowa entry on the National Register of Historic Places.

Funds for the restorations have been raised through memberships in the Association, house tours, an annual fall antique fair held on the house grounds and an annual spring antique fair. In 1972 a cookbook, A Compendium of Victorian Cookery \& Reliable Recipes, was compiled featuring some of the recipes and household hints from various authentic late Victorian cookbooks belonging to Waterloo and Cedar Falls residents.

Except for January through March, the Russell House is open regularly on Wednesday and Sunday afternoons for tours from 1:30 P.M. to 4:00 P.M. Tours may be scheduled at any time by special request. Except for Association members, the adult fee tour is $50 \phi$. 
Copyright of Annals of Iowa is the property of State of Iowa, by \& through the State Historical Society of Iowa and its content may not be copied or emailed to multiple sites or posted to a listserv without the copyright holder's express written permission. However, users may print, download, or email articles for individual use. 